\title{
Assessment of the impact of technical factors on the quality of colonoscopy - a preliminary report
}

\author{
Ocena wpływu czynników technicznych na jakość kolonoskopii w materiale \\ własnym - doniesienie wstępne
}

\author{
Marek Pastuszak ${ }^{1}$, Małgorzata Pastuszak², Krzysztof Groszewski ${ }^{3}$, Stanisław Wojtuñ ${ }^{4}$, Jerzy Gil ${ }^{4}$ \\ 1Provincial Hospital, Elblag, Poland \\ 2Department of Internal Medicine, Internal Medicine Center Elvita, Elblag, Poland \\ ${ }^{3}$ Gastrointestinal Endoscopy Unit, Provincial Hospital, Elblag, Poland \\ ${ }^{4}$ Department of Gastroenterology, Military Institute of Health Services, Warsaw, Poland
}

Prz Gastroenterol 2013; 8 (1): 50-56

DOI: $10.5114 / p g .2013 .34183$

Key words: quality of colonoscopy, technical aspects, polyp detection rate.

Słowa kluczowe: jakość w kolonoskopii, czynniki techniczne, współczynnik wykrywania polipów.

Address for correspondence: Marek Pastuszak MD, Provincial Hospital, 146 Królewiecka St, 82-300 Elblag, Poland, phone: +48 5523959 39, e-mail: marcuswp@wp.pl

\begin{abstract}
Introduction: The debate over the quality of colonoscopy typically includes technical factors such as the resolution of the camera (standard vs. high definition), the physical parameters (thickness, stiffness, pediatric colonoscope vs. standard, variable stiffness endoscope) and the possibility to use additional techniques (narrow band imaging, auto fluorescence imaging, retrograde viewing device, cap-assisted colonoscopy, carbon dioxide insufflation or water infusion). The cecal intubation rate and patient tolerance of endoscopy are usually used as determinants of the quality of colonoscopy.

Aim: The study evaluated the possible impact of technical factors related to presentation of the endoscopic image on the quality measured by the polyp detection rate/adenoma detection rate (PDR/ADR). The model used in the study was constructed $i$ the way to minimize the impact of operatordependent factors (retrospective analysis of derived from the population routinely tested - diagnostic endoscopy done by a single endoscopist).

Material and methods: The model used in the study was constructed in the way to minimize the impact of operator dependent factors (retrospective analysis of archival data, single endoscopist, the population of routinely examined patients - diagnostic endoscopies).

Results: The results suggest that the impact of analyzed technical factors may be statistically significant. Reported differences are limited to the smallest polyps, up to $5 \mathrm{~mm}$, located in the distal intestine (tubular adenomas and hyperplastic polyps).

Conclusions: The results indicate no statistically significant difference in the "advanced adenoma" detection rate, suggesting their limited clinical significance, but drawing atten-
\end{abstract}

\section{Streszczenie}

Wstęp: W dyskusji nad jakością badań kolonoskopowych zwykle uwzględnia się czynniki techniczne, takie jak: rozdzielczość aparatu (standardowa vs HD), jego parametry fizyczne (grubość, sztywność, aparaty pediatryczne vs standardowe, regulowana sztywność), a także stosowanie technik dodatkowych (obrazowanie w wąskim paśmie, obrazowanie $z$ autofluorescencją, zastosowanie optyki wstecznej, aparaty z przezroczystą nasadką) oraz specjalnych technik badania (insuflacja dwutlenkiem węgla, immersja wodna). Jako wykładników jakości badań kolonoskopowych zazwyczaj używa się wspótczynnika intubacji kątnicy oraz tolerancji badania przez pacjenta.

Cel: Ocena wpływu czynników technicznych związanych ze sposobem prezentacji uzyskanego obrazu endoskopowego na jakość ocenianą przez współczynnik wykrywalności polipów/współczynnik wykrywalności gruczolaków (PDR/ADR).

Materiat i metody: $\mathrm{W}$ badaniu zastosowano model, który minimalizuje wpływ elementów zależnych od operatora (analiza danych archiwalnych, badania wykonane przez jednego endoskopistę posiadającego doświadczenie w użytkowaniu wszystkich używanych aparatów, pacjenci z populacji rutynowo badanej - endoskopie diagnostyczne).

Wyniki: Stwierdzono możliwy istotny statystycznie wpływ analizowanych czynników technicznych na współczynnik wykrywalności polipów stanowiący wykładnik jakości kolonoskopii w używanym modelu.

Wnioski: Charakterystyka wykazanych różnic dotyczących polipów najmniejszych (do $5 \mathrm{~mm}$ ), zlokalizowanych w dystalnym odcinku jelita o budowie gruczolaków cewkowych i polipów hiperplastycznych, przy braku istotnych różnic w zakresie 
tion to a technical aspect that could potentially affect the results of clinical trials.

\section{Introduction}

Colorectal cancer (CRC) constitutes one of the major health, but also sociological and economic problems of the modern world. Increasing incidence of CRC in Poland in combination with the unsatisfactory results of the clinical stage of disease at diagnosis, causes increasing importance of preventive interventions. A special position in the field of CRC prophylaxis is occupied by the preventive colonoscopy programs as the most effective method to improve the health situation. The high cost of screening programs linked to the need to cover the entire population is the main factor stimulating activity aimed at improving their effectiveness. The discussion on the possibility of improving the effectiveness of prevention programs includes sociological and social factors (such as the need to reach the widest possible group of people and to improve the attendance rate), medical factors (identification of the optimal target group for prevention activities, and in particular, the age limits and intervals - perhaps including gender) as well as quality issues of colonoscopy [1].

The detection rate for polypoid lesions, particularly colorectal adenomas, occupies an important place among the quality measures mentioned in the discussion on the quality of colonoscopic examinations together with the rate of complete colonoscopy (defined as cecal intubation with appendiceal orifice visualization and examination of the proximal part of the ileo-cecal valve) [2]. This factor appears to be of essential importance as a measure of efficiency of colonoscopic examination because of the biology of colorectal cancer and the main purpose of the screening program.

Most of the research in the field of the quality of colonoscopy is focused on the assessment of the impact of examined factors on the ability to intubate the cecum. The effectiveness of pediatric and variable stiffness instruments was evaluated in so-called "difficult colonoscopies" [3-5] as well as the use of sedation/analgesia and the level of sedation [6-8], the effectiveness of different methods of bowel preparation and the effect of colonoscopist experience [9]. Some studies attempted to investigate the possible influence of different instruments on cecal intubation rate and time [6]. The difference in adenoma detection rate was studied too, but using different types of endoscopes (instruments of different generations: high resolution vs. standard resolu- „gruczolaków zaawansowanych”, sugeruje ich niewielkie znaczenie kliniczne, jednak zwraca uwagę na dotychczas pomijany aspekt techniczny, który może wpływać na wyniki badań klinicznych.

tion $[10,11]$ or standard instruments vs. instruments with the ability to use additional techniques such as narrow band imaging (NBI), auto fluorescence imaging (AFI), or retrograde viewing [12-17]).

The debate over quality indicators of colonoscopic examination included operator-dependent elements (such as the experience of the clinician and technical competence) as well as technical elements such as diameter of the instrument (for example ultrathin endoscopes), variable stiffness, and optical resolution [18-20].

\section{Aim}

The main aim of this study is to assess the potential impact of technical factors related to the method of presentation of the endoscopic image (using input data obtained with the use of transducers characterized by similar technical parameters) on the quality of colonoscopy examination measured by the polyp detection rate/adenoma detection rate (PDR/ADR) using the model constructed in a way reducing the possible influence of elements associated with the operator.

\section{Material and methods}

In order to estimate the possible impact of technical factors related to the method of processing and presentation of the endoscopic image, two different videoendoscopic systems of the same generation were used in the study. The technical parameters of the used systems did not differ significantly (both using standard video converters working in standard resolution (SD); systems were obtained as a result of a tender procedure with similar technical requirements, but originated from different manufacturers). In order to reduce the impact of group selection procedure a retrospective assessment model of archival data was used in the study. The analyzed data were obtained during routine colonoscopic examinations performed by a single endoscopist in the Gastrointestinal Endoscopy Unit. The endoscopist was experienced in the use of both systems studied. All patients underwent elective examination during routine activity of the unit regardless of the underlying indication for referral for endoscopy (the indication for referral for colonoscopy was not part of the procedure of qualifying for the study - the population studied is a part of the population routinely examined in the unit). Only complete examinations were enrolled (defined as cecum 
intubation or intubation of cecum and distal ileum). Patients with inadequate bowel preparation, patients with a history of previous surgery (resection - shortening the colon) and patients with macroscopic tumor or infiltration (both neoplastic and inflammatory) were excluded. Cases of cancer identified in the polyp were included in the study (diagnosis according to the histopathological examination after biopsy performed during the analyzed colonoscopy). Homogeneous groups in terms of age and gender were randomly selected to be compared in the analysis. The whole analyzed group consisted of 542 patients divided into two groups of 271 patoents according to the used endoscopic system (groups A and B). The population characteristics are presented in the table. The histological structure of detected lesions, their number, size and location were analyzed. The lesions were divided into groups according to their size (largest dimension up to $5 \mathrm{~mm}, 6-9 \mathrm{~mm}$, $10 \mathrm{~mm}$ and above - categories W1, W2 and W3) and their location (rectum, sigmoid colon with descending colon, transverse colon with both flexures splenic and hepatic, ascending colon with cecum - categories L1, L2, $\mathrm{L} 3$ and $\mathrm{L} 4$ respectively). Cases of cancer, adenomas with high-grade dysplasia ( $\mathrm{HG}$ ) or with a villous component or tubular adenomas of at least $10 \mathrm{~mm}$ in diameter were classified as "advanced neoplasia". The whole analyzed material consisted of 657 adenomatous lesions detected.

\section{Statistical analysis}

Statistical analysis using the $\chi^{2}$ test, Wilcoxon-MannWhitney $U$ test and test of proportion (ratio) was performed using the open statistical software "R-project".

Table I. Characteristics of the population

Tabela I. Charakterystyka badanej grupy

\begin{tabular}{lccccc} 
Parameter & Entire population & \multicolumn{2}{c}{ Group A } & \multicolumn{2}{c}{ Group B } \\
\cline { 3 - 6 } & & $\mathrm{F}$ & $\mathrm{M}$ & $\mathrm{F}$ & $\mathrm{M}$ \\
\hline$n$ & 542 & 176 & 95 & 176 & 95 \\
\hline Mean & 53.75 & 52.77 & 55.54 & 52.77 & 55.57 \\
\hline SD & 15.52 & 15.66 & 15.27 & 15.66 & 15.19 \\
\hline Median & 54 & 53 & 56 & 53 & 56 \\
\hline Value of $p$ & 0.9669 & 0.9607 & 0.9926 & (Between groups A and B)
\end{tabular}

Table II. Differences in polyp detection rate ( $p$-value) according to their size and location Tabela II. Różnice w wykrywaniu obecności polipów ( $p$-value) w zależności od wielkości i lokalizacji

\begin{tabular}{lccccc} 
& All & L1 & L2 & L3 & L4 \\
\hline \multicolumn{7}{c}{ Entire population } \\
\hline All & 0.0014 & 0.012 & 0.034 & 0.011 & NS \\
\hline W1 & 0.0002 & NS & 0.0047 & NS & NS \\
\hline W2 & 0.037 & 0.044 & NS & NS & NS \\
\hline W3 & NS & NS & NS & NS & NS \\
\hline \multicolumn{7}{c}{ Women } \\
\hline All & 0.03 & NS & NS & 0.039 & NS \\
\hline W1 & 0.043 & NS & NS & NS & NS \\
\hline W2 & NS & NS & NS & NS & NS \\
\hline W3 & NS & NS & NS & NS & NS \\
\hline \multicolumn{7}{c}{ Men } \\
All & 0.016 & NS & NS & NS & NS \\
\hline W1 & 0.0008 & NS & 0.013 & NS & NS \\
\hline W2 & NS & 0.038 & NS & NS & NS \\
\hline W3 & NS & NS & NS & NS & NS
\end{tabular}

Table III. Differences in number of detected polyps ( $p$-value) according to their size and location

Tabela III. Różnice w wykrywaniu liczby polipów (p-value) w zależności od wielkości i lokalizacji

\begin{tabular}{lccccc} 
& All & L1 & L2 & L3 & L4 \\
\hline \multicolumn{7}{c}{ Entire population } \\
\hline All & 0.00027 & 0.008 & 0.026 & 0.011 & NS \\
\hline W1 & 0.0002 & 0.035 & 0.0039 & NS & NS \\
\hline W2 & 0.021 & 0.018 & NS & NS & NS \\
\hline W3 & NS & NS & NS & NS & NS \\
\hline \multicolumn{7}{c}{ Women } \\
\hline All & 0.017 & 0.049 & NS & 0.033 & NS \\
\hline W1 & 0.03 & NS & NS & NS & NS \\
\hline W2 & NS & NS & NS & NS & NS \\
\hline W3 & NS & NS & NS & NS & NS \\
\hline \multicolumn{7}{c}{ Men } \\
All & 0.0019 & NS & NS & NS & NS \\
\hline W1 & 0.0016 & NS & 0.0056 & NS & NS \\
\hline W2 & 0.045 & 0.013 & NS & NS & NS \\
\hline W3 & NS & NS & NS & NS & NS
\end{tabular}


Table IV. Mean number of polyps/person in individual subjects of groups A and B

Tabela IV. Średnia liczba polipów przypadająca na osobę u poszczególnych pacjentów $w$ grupach $A$ i $B$

\begin{tabular}{|c|c|c|c|c|c|c|c|c|c|c|c|}
\hline & All & L1 & L2 & L3 & $\llcorner 4$ & & All & L1 & L2 & L3 & L4 \\
\hline \multicolumn{12}{|c|}{ Entire population } \\
\hline All & 1.44 & 0.30 & 0.61 & 0.29 & 0.24 & All & 0.98 & 0.16 & 0.43 & 0.20 & 0.19 \\
\hline W1 & 1.04 & 0.25 & 0.47 & 0.20 & 0.125 & W1 & 0.69 & 0.13 & 0.29 & 0.15 & 0.121 \\
\hline W2 & 0.25 & 0.04 & 0.06 & 0.06 & 0.07 & W2 & 0.11 & 0.004 & 0.04 & 0.04 & 0.025 \\
\hline W3 & 0.15 & 0.01 & 0.07 & 0.025 & 0.04 & W3 & 0.18 & 0.02 & 0.09 & 0.011 & 0.04 \\
\hline \multicolumn{12}{|c|}{ Women } \\
\hline All & 1.13 & 0.23 & 0.45 & 0.25 & 0.198 & All & 0.82 & 0.12 & 0.39 & 0.15 & 0.17 \\
\hline W1 & 0.84 & 0.20 & 0.35 & 0.19 & 0.102 & W1 & 0.62 & 0.09 & 0.29 & 0.11 & 0.13 \\
\hline W2 & 0.18 & 0.011 & 0.05 & 0.039 & 0.07 & W2 & 0.09 & 0.005 & 0.04 & 0.034 & 0.01 \\
\hline W3 & 0.11 & 0.011 & 0.056 & 0.017 & 0.022 & W3 & 0.11 & 0.017 & 0.062 & 0.005 & 0.028 \\
\hline \multicolumn{12}{|c|}{ Men } \\
\hline All & 2.01 & 0.44 & 0.88 & 0.38 & 0.305 & All & 1.27 & 0.24 & 0.50 & 0.31 & 0.221 \\
\hline W1 & 1.41 & 0.32 & 0.69 & 0.22 & 0.168 & W1 & 0.82 & 0.2 & 0.28 & 0.23 & 0.105 \\
\hline W2 & 0.38 & 0.1 & 0.09 & 0.11 & 0.063 & W2 & 0.16 & 0 & 0.05 & 0.05 & 0.052 \\
\hline W3 & 0.22 & 0.01 & 0.09 & 0.04 & 0.073 & W3 & 0.29 & 0.04 & 0.16 & 0.02 & 0.063 \\
\hline
\end{tabular}

\section{Results}

In the analysis of 542 endoscopic examinations polypoid lesions were found in 270 cases (49.82\%). In group A, polyps were detected in 154 (56.83\%) in group B in 116 (42.8\%) cases, showing a statistically significant difference $(p=0.0014)$. Also regarding gender, statistically significant differences between tested groups were found in the subgroup of women $(p=0.03)$ and men $(p=0.016)$ - in $85(48.3 \%)$ vs. $64(36.4 \%)$ cases of women and $69(72.6 \%)$ vs. 52 (54.7\%) cases of men respectively. As regards the size of lesions, significant differences were found in subgroups of the smallest polyps (up to $5 \mathrm{~mm}$ - category W1: $p=0.0002$ ), and polyps of $6-9 \mathrm{~mm}$ size (W2: $p=0.037$ ). Comparing women and men, observed differences reached the level of statistical significance only in the subgroup of polyps up to $5 \mathrm{~mm}$ in size (W1: $p=0.04$ and $p=0.0008$, respectively).

The analysis of the location of detected lesions showed significant differences for the location from rectum to hepatic flexure (respectively $L 1: p=0.012$; $\mathrm{L} 2: p=0.034, \mathrm{~L} 3: p=0.011)$. The differences for the location in cecum and ascending colon did not reach statistical significance ( $L 4: p=0.42$ ). Including gender of subjects, significant differences were found only in the subgroup of lesions located in the transverse colon with both flexures in women (category L3: $p=0.039$ ). When the analysis takes into account the location and magnitude of lesions simultaneously, significant differences concerned only the smallest polyps (W1) located in the sigmoid and descending colon (L2) and polyps of category W2 (6 $\mathrm{mm}$ to $9 \mathrm{~mm}$ ) located in the rectum ( $p=0.0047$ and $p=0.044$ respectively). Statistical significance was found in men in both subgroups ( $p=0.013$ and $p=0.038$ ). The analysis of the number of polyps found per subject showed similar results except for three cases: the differences reached the level of statistical significance for the smallest rectal polyps (W1 L1: $p=0.035$ ), for the subgroup of polyps of medium size in men (W2: $p=0.045$ ) and the subgroup of polyps located in the rectum in women (L1: $p=0.049$ ).

The analysis of histological structure of lesions showed significant differences for adenomas regardless of their size and location ( $p=0.005)$, including those of diameter up to $9 \mathrm{~mm}$ (categories W1 and W2: $p=0.01$ and $p=0.002$ respectively), and taking into account the location of lesions the differences were significant for the smallest adenomas (up to $5 \mathrm{~mm}$ : W1) located in the sigmoid and descending colon (L2: $p=0.01$ ) and for medium size polyps $(6-9 \mathrm{~mm})$ detected in the cecum and ascending colon ( $L 4, W 2: p=0.01)$. As regards the gender of subjects, the differences reached the level of statistical significance in men in the subgroups mentioned above ( $p=0.02, p=0.01, p=0.02, p=0.02)$, with the exception of the last case $(L 4, W 2)$ where the significant differences occurred in women ( $p=0.02, p=0.44$ for men). In the case of tubular adenomas similar results were found. When the histological structure of adenomas showed the presence of villous elements only differences found in the subset of largest lesions detected 
A

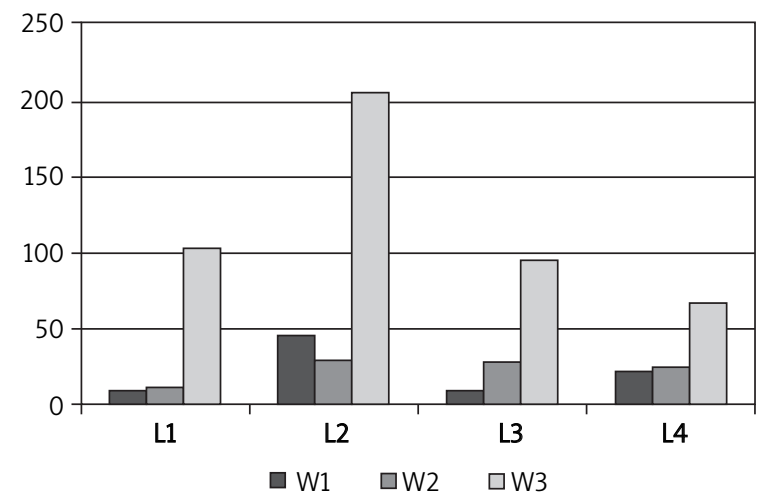

B

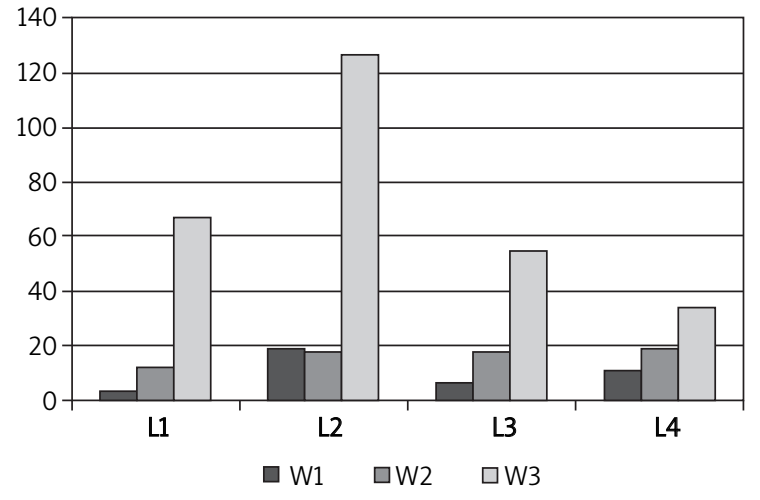

C

D
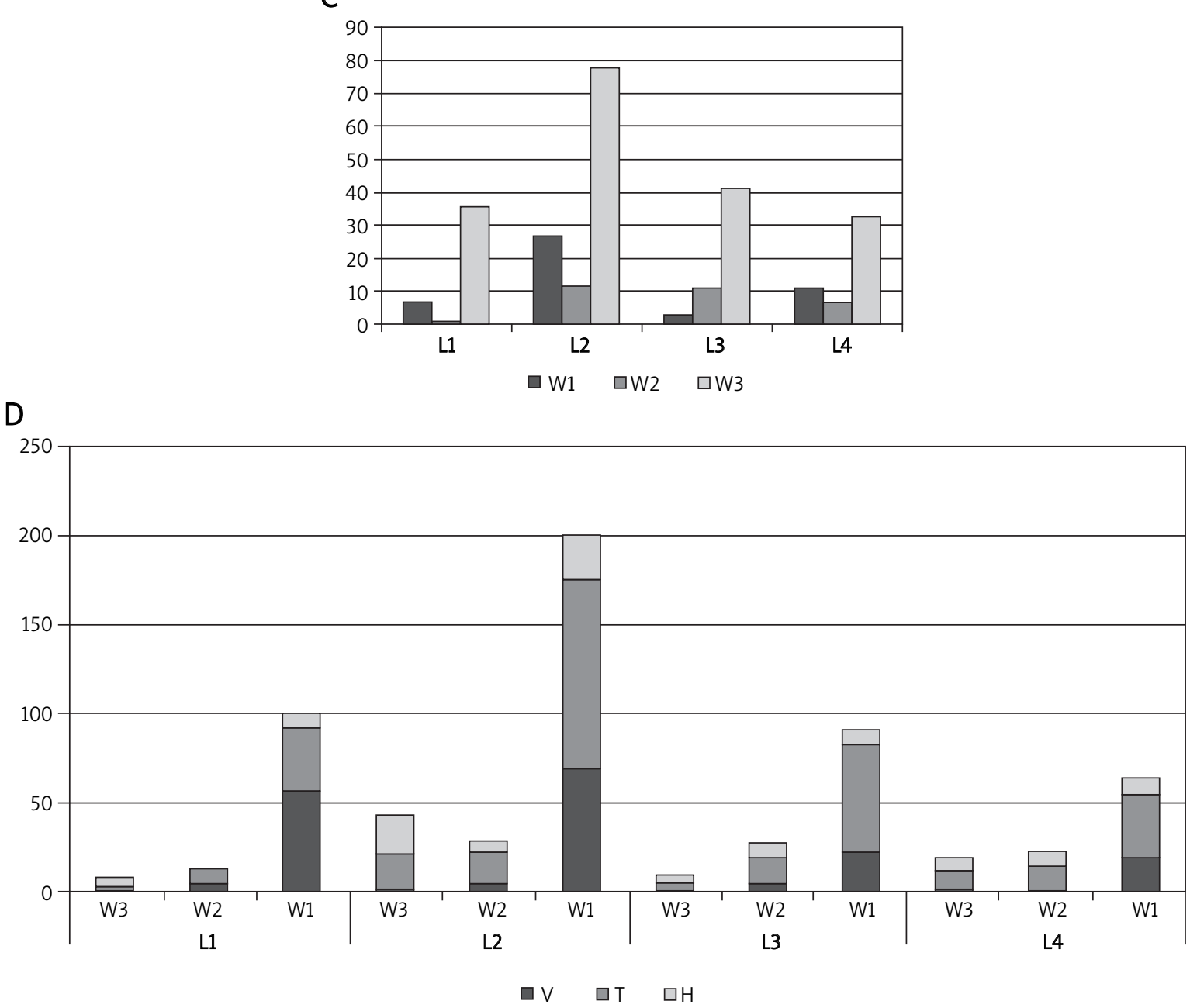

Fig. 1. Analysis of detected polyps according to their size and location: A - entire population, B - group A, C - group B, D - according to the histological structure $H$ - hyperplastic, $T$ - tubular adenoma, $V$-adenoma with villous elements

Ryc. 1. Analiza wykrytych polipów w zależności od lokalizacji i wielkości: $A-w$ całej populacji, $B-w$ grupie $A$, $C-w$ grupie $B, D-z$ uwzględnieniem budowy

$H$ - hiperplastyczne, $T$ - gruczolaki cewkowe, $V$-gruczolaki z elementami kosmkowymi 
in the sigmoid and descending colon reached the borderline level of significance ( $p=0.046$ for entire population and $p=0.051$ for men). There were no statistically significant differences in the analysis of the presence of advanced neoplasia. In the case of non-adenomatous polyps, significant differences in the subgroup of the smallest polyps ( $p=0.01, p=0.027$ for women) and in the subgroup of polyps located in the rectum were observed (only entire population: $p=0.02$; for women: $p=0.07$ ). The differences observed in the subset of polyps located in the transverse colon (with both flexures) in women reached the borderline level of significance $(p=0.0467)$. Similar results for hyperplastic polyps were observed ( $p=0.023$ for transverse colon in women). The analysis of the number of polyps detected in individual colonoscopies showed analogous differences of similar significance. Additionally, statistical significance in the number of tubular adenomas of medium size detected in the rectum was found (W2: $p=0.03$; $p=0.024$ for men). Differences in the number of polyps with the presence of villous elements occurred too (largest for sigmoid colon: $p=0.026$, for hepatic flexure: $p=0.045)$ as well as differences in the number of medium size $(6-9 \mathrm{~mm})$ lesions in the cecum and ascending colon in women $(p=0.044)$.

Significant differences in the analysis of the frequency of particular types of all 657 polyps detected in both groups ( $\mathrm{A}$ and $\mathrm{B}$ ) occurred and concerned tubular adenomas ( $p=0.0004$, including the smallest: $p=0.018$ and detected in sigmoid and descending colon: $p=0.015$, as well as medium size: $p=0.0001$ located in cecum/ ascending colon: $p=0.005$ ) and hyperplastic polyps up to $5 \mathrm{~mm}$ in size localized in the rectum $(p=0.006)$. In the case of advanced neoplasia a statistically significant difference occurred only for the smallest polyps with villous elements up to $5 \mathrm{~mm}$ in size located in the sigmoid and descending colon $(p=0.004)$.

\section{Discussion}

The main aim of this study was to develop a model for assessing the potential impact of technical factors related to the method of presentation of the endoscopic image on the quality of colonoscopic examinations, as one of the elements rarely taken into consideration among the factors potentially modifying the results of studies in other models of research, in which the potential influence of technical factors on the analyzed data is usually not taken into account at all. The resolution of the image and the physical parameters (diameter of the instrument, adjustable stiffness) are the most common technical factors taken into account in studies based on the analysis of endoscopic procedures. The data presented in our study suggest the possibility of an additional factor poten- tially affecting the quality of colonoscopy, usually overlooked, associated with the differences in the method of endoscopic image presentation. The analyzed model constructed in a way that minimizes the impact of other elements (single endoscopist, a random selection of the study group derived from the population of patients undergoing routine examinations, endoscopes of the same generation, with similar technical parameters studied, inadequate bowel preparation excluded, only examinations with successful cecal intubation enrolled, and finally the detection rate of polyps/adenomas selected as the quality indicator) indicates a statistically significant effect of the factor studied. However, the construction of the model, which limits the size of the analyzed population, is the major constraint, not allowing us to draw general conclusions, but only drawing attention to a potential, usually overlooked factor that may influence the results. As anticipated, significant differences were found concerning the smallest lesions up to $5 \mathrm{~mm}$ in size located mainly in the distal parts of the colon. Importantly, there were no significant differences in the frequency of detection of the clinically most significant lesions, including cases of "advanced adenoma" (cases of macroscopic tumors were excluded; the cases of cancer analyzed in the study are lesions of the type "cancer in the polyp"). Detected lesions mainly consisted of small tubular adenomas and hyperplastic polyps; hence their clinical significance seems to be debatable.

The analysis of a local population in terms of frequency, location, size and histological structure of detected polypoid lesions creates an additional value of the study.

\section{Conclusions}

The study demonstrated the statistically significant impact of technical factors related to the method of endoscopic image presentation on the quality of colonoscopic examinations estimated by the use of polyp detection rate/adenoma detection rate (PDR/ADR). However, differences found in the study mainly relate to small lesions defined as polyps up to $5 \mathrm{~mm}$ in size with the histological structure of hyperplastic polyps or tubular adenomas with low grade dysplasia. There were no statistically significant differences in the detection rate of "advanced adenomas". The results suggest that the impact of analyzed technical factors, usually overlooked in the analysis of data, may be statistically significant. However, characteristics of the detected differences may call into question their clinical significance.

\section{References}

1. Bair D, Pham J, Seaton MB, et al. The quality of screening colonoscopies in an office-based endoscopy clinic. Can J Gastroenterol 2009; 23: 41-7. 
2. Millan MS, Gross P, Manilich E, et al. Adenoma detection rate: the real indicator of quality in colonoscopy. Dis Colon Rectum 2008; 51: 1217-20.

3. Kaffes AJ, Mishra A, Ding SL, et al. A prospective trial of variable stiffness pediatric vs. standard instrument colonoscopy. Gastrointest Endosc 2003; 58: 685-9.

4. Saifuddin T, Trivedi M, King PD, et al. Usefulness of a pediatric colonoscope for colonoscopy in adults. Gastrointest Endosc 2000; 51: 314-7.

5. Xie Q, Chen B, Liu L, et al. Does the variable-stiffness colonoscope makes colonoscopy easier? A meta-analysis of the efficacy of the variable stiffness colonoscope compared with the standard adult colonoscope. BMC Gastroenterol 2012; 12: 151.

6. Arasaradnam RP, Hurlstone PD. Does type of instrument influence colonoscopy performance and sedation practice? World J Gastroenterol 2007; 13: 486-7.

7. Kessler WR, Rex DK. Impact of bending section length on insertion and retroflexion properties of pediatric and adult colonoscopes. Am J Gastroenterol 2005; 100: 1290-5.

8. Radaelli F, Meucci G, Sgroi G, et al. Technical performance of colonoscopy: the key role of sedation/analgesia and other quality indicators. Am J Gastroenterol 2008; 103: 1122-30.

9. Barclay RL, Vicari JJ, Doughty AS, et al. Colonoscopic withdrawal times and adenoma detection during screening colonoscopy. NEJM 2006; 355: 2533-41.

10. Adler A, Wegscheider K, Lieberman D, et al. Factors determining the quality of screening colonoscopy: a prospective study on adenoma detection rates, from 12134 examinations (Berlin colonoscopy project 3, BECOP-3). Gut 2012 Mar 22.

11. Banks MR, Haidry R, Butt MA, et al. High resolution colonoscopy in a bowel cancer screening program improves polyp detection. World J Gastroenterol 2011; 17: 4308-13.

12. East JE, Suzuki N, Stavrinidis M, et al. Narrow band imaging for colonoscopic surveillance in hereditary non-polyposis colorectal cancer. Gut 2008; 57: 65-70.

13. Dinesen L, Chua TJ, Kaffes AJ. Meta-analysis of narrow-band imaging versus conventional colonoscopy for adenoma detection. Gastrointest Endosc 2012; 75: 604-11.

14. Moriichi K, Fujiya M, Sato R, et al. Back-to-back comparison of auto-fluorescence imaging (AFI) versus high resolution white light colonoscopy for adenoma detection. BMC Gastroenterol 2012; 12: 75.

15. Siersema PD, Rastogi A, Leufkens AM, et al. Retrograde-viewing device improves adenoma detection rate in colonoscopies for surveillance and diagnostic workup. World J Gastroenterol 2012; 18: 3400-8.

16. Leufkens AM, DeMarco DC, Rastogi A, et al. Effect of a retrograde-viewing device on adenoma detection rate during colonoscopy: the TERRACE study. Gastrointest Endosc 2011; 73 : 480-9.

17. Hotta K, Katsuki S, Ohata K, et al. A multicenter, prospective trial of total colonoscopy using a short double-balloon endoscope in patients with previous incomplete colonoscopy. Gastrointest Endosc 2012; 75: 813-8.

18. Luo DJ, Hui AJ, Yan KK, et al. A randomized comparison of ultrathin and standard colonoscope in cecal intubation rate and patient tolerance. Gastrointest Endosc 2012; 75: 484-90.
19. Sato K, Ito S, Shigiyama F, et al. A prospective randomized study on the benefits of a new small-caliber colonoscope. Endoscopy 2012; 44: 746-53.

20. Ng SC, Tsoi KK, Hirai HW, et al. The efficacy of cap-assisted colonoscopy in polyp detection and cecal intubation: a metaanalysis of randomized controlled trials. Am J Gastroenterol 2012; 107: 1165-73. 